\title{
Melatonin and alpha lipoic acid attenuate lopinavir/ritonavir - induced testicular toxicity in albino rats
}

\author{
Elias Adikwu*, Brambaifa Nelson, Wolfe Atuboyedia Obianime \\ Department of Pharmacology, Faculty of Basic Medical Sciences, \\ University of Port Harcourt, Choba, Rivers State, Nigeria
}

Received: April 2017; Accepted: May 2017

\begin{abstract}
The use of lopinavir/ritonavir (LPV/r) could be associated with testicular toxicity as a limiting factor. The present study evaluated the effects of melatonin (MT) and alpha lipoic (ALA) acid on LPV/r-induced testicular toxicity in male albino rats. Eighty five male albino rats used for this study were randomized into 6 groups (A-F). Rats in groups A1 and A2 served as placebo and solvent control and were orally exposed to water and $1 \%$ ethanol, respectively. Rats in group B were exposed to oral doses of MT (10 mg kg $\left.\mathrm{mg}^{-1} / \mathrm{day}\right), \mathrm{ALA}\left(10 \mathrm{mg} \mathrm{kg}{ }^{-1} / \mathrm{day}\right)$ and combined doses of MT and ALA, respectively. Rats in group C were exposed to oral doses of LPV/r (22.9/5.71 - 91.4/22.9 $\mathrm{mg} \mathrm{kg}^{-1} /$ day), respectively. Rats in group D-F were exposed to oral doses of MT (10 mg kg-1/day), ALA (10 mg kg-1/day) and combined doses of MT and ALA prior to oral exposure to LPV/r (22.9/5.71 - 91.4/22.9 $\mathrm{mg} \mathrm{kg}^{-1} /$ day), respectively. At the end of 60 days of exposure to drugs, rats were sacrificed; blood was collected and serum extracted and evaluated for testosterone. Testes were collected and evaluated for sperm parameters. LPV/r-treated rats showed significant $(\mathrm{P}<0.05)$ and dose-dependent decreases in sperm count, sperm motility, sperm viability and serum testosterone levels with increases in abnormal sperm cells, debris, and primordial sperm cells when compared to placebo control. However, LPV/r-induced changes in sperm parameters and serum testosterone levels were attenuated in rats pretreated with MT and ALA. The best effects were observed in rats pretreated with combined doses of MT and ALA. Melatonin and alpha lipoic acid have potential to reduce testicular toxicity associated with lopinavir/ritonavir treatment.
\end{abstract}

Keywords: lopinavir/ritonavir, testis, toxicity, antioxidants, rats

\section{Introduction}

Melatonin (MT) is produced by the pineal gland during the dark phase at night and its production is acutely suppressed by light (Ventura et al., 2000). It is an amphiphlic antioxidant that is soluble in lipid and aqueous phases. In addition to the antioxidant effect of MT, its secondary and tertiary metabolites can also neutralize numerous toxic oxygen derivatives via cascade of reactions. Also,
MT has anti-inflammatory effect and can inhibit the production of tumor necrosis factor alpha (TNF- $\alpha$ ) and other pro-inflammatory cytokines. It can regulate an immense diversity of physiological processes, including reproductive cycles (Ekmekcioglu, 2006). Regulation of reproductive processes can occur through its receptors found in the epididymis, and on spermatozoa (Casao et al., 2010). It can stimulate the hypothalamus-hypophysis-gonadal system thereby regulating testicular functions (Sarabia et al., 2011). Furthermore, in addition to its regulatory effects on testicular function, studies have shown that it can mitigate

\footnotetext{
*adikwuelias@gmail.com
} 
xenobiotic-induced testicular damage (Mirhoseini et al., 2014; Sarabia et al., 2009). Also, it could up-regulate and stimulate the testicular antioxidant effects of glutathione, superoxide dismutase, and catalase, in xenobiotic-intoxicated rats (Othman et al., 2016).

Alpha lipoic acid (ALA) is an essential cofactor for the $\mathrm{E}_{2}$ component of $\alpha$-keto-acid dehydrogenase complexes, exclusively located in mitochondria. It catalyzes the oxidative carboxylation of pyruvate and plays a fundamental role in carbohydrate metabolism and bioenergetics (Packer et al., 2009). It is a water and fat-soluble antioxidant that crosses biological membranes easily and suppresses free radicals, thereby preventing free radical-induced oxidative damage. Dihydrolipoic acid (reduced form of ALA) is a stronger antioxidant than lipoic acid and can act synergistically with other antioxidants such as glutathione, ascorbate and tocopherol (Navari-Izzo et al., 2002). Also, in addition to its antioxidant property it has anti-inflammatory effect and can inhibit the release of pro-inflammatory cytokines, including TNF- $\alpha$ and interleukin 6 (IL-6) (Sola et al., 2005). Studies have associated ALA with plethora of physiological functions which include regulation of reproductive function. The provision of adequate antioxidant environment that regulates signal transduction in hypothalamus-testicular axis leading to increase sperm production is a vital function of ALA (Minaii et al., 2014). Also, it could minimize testicular oxidative stress and increased semen quality (Peruma et al., 2013). Studies have shown inherent potential in ALA as a recipe for drug and chemical agentinduced testicular damage (Lebda et al., 2014; Prahalathan et al., 2006). Furthermore, pronounce effect characterized by synergistic activity has been reported with concurrent use of MT and ALA (Mukherjee et al., 2011).

Lopinavir/ritonavir (LPV/r) is a fixed dose protease inhibitor used as a component of highly active antiretroviral therapy. It has contributed immensely toward drastic reduction in mortality and morbidity associated with human immune deficiency virus (Yeni et al., 2002). Despite the therapeutic benefits associated with the use of LPV/r, its lifelong use could be accompanied by toxicities which include testicular toxicity (Bujan et al., 2007; Dulioust et al., 2002). The use of LPV/r combination has been associated with decrease in sperm quality, erectile dysfunction, decrease libido, ejaculatory disturbance, and orgasmic disorders (Collazos, 2007; Colson et al., 2002). Furthermore, $\mathrm{LPV} / \mathrm{r}$ associated testicular toxicity could be characterized by oxidative stress, because it has been associated with mitochondria damage leading to the production of oxidative radicals (Pavili et al., 2013). Sperm cells have large quantity of polyunsaturated acid which could be destroyed via lipid peroxidation in the presence of excess oxidation radicals (Diehl et al., 2013). In the light of the above information, the present study was designed to evaluate the effects of MT and ALA on LPV/r-induced testicular toxicity in albino rats. The effects of these antioxidants were evaluated on LPV/r-induced testicular levels of sperm count, motili- ty, abnormal sperm cells (morphology), debris, primordial sperm cells and serum testosterone in albino rats.

\section{Materials and methods}

\section{Animals}

Eighty five male albino rats used for this study were obtained from the animal house of the University of Port Harcourt, Choba, Rivers State. The rats were randomized into separate cages ( 5 per cage) and allowed to acclimatize for 2 weeks in a well-ventilated room, maintained at a room temperature of $28 \pm 2{ }^{\circ} \mathrm{C}$, under $12 \mathrm{~h} \mathrm{light/dark} \mathrm{cy-}$ cle. The rats were allowed free access to food and water $\mathrm{ad}$ libitum. All rats used for this study were handled in accordance with Directive 2010/63/EU of the European Parliament and the Council on the protection of animals used for scientific purposes.

Drugs

LPV/r used for this study was manufactured by Myland Laboratories Limited India. The pure samples of MT and ALA used were supplied by Shijiazhuang AO Pharm Import and Export Co Ltd China. All other chemicals used for this study are of analytical grade. LPV/r (22.9/5.71, 45.6/11.4 and 91.4/22.9 $\mathrm{mg} \mathrm{kg}^{-1} /$ day) which represent 2, 4 and 8 times the clinical dose (Hull et al., 2009), MT (10 mg $\left.\mathrm{kg}^{-1}\right)$ and ALA $\left(10 \mathrm{mg} \mathrm{kg}^{-1}\right)$ were used for this study (Ali et al., 2013; Bilginoğlu et al., 2014). LPV/r was dissolved in $1 \%$ ethanol (Reyskens et al., 2013), ALA was dissolved in water, while MT was dissolved in $1 \%$ ethanol and diluted with normal saline (Shagirtha et al., 2011).

\section{Experimental protocol}

Rats used for this study were divided into 6 groups (A-F). Group A served as the control and was divided into two sub-groups A1 and A2 of 5 rats each. Rats in group A1 (placebo control) and group A2 (solvent control) were orally treated with normal saline and $1 \%$ ethanol, respectively for 60 days. Groups B-F contained 15 rats each which were divided into 3 sub-groups of 5 rats each. Rats in group B were orally exposed to MT (10 mg kg-1/day), ALA (10 $\mathrm{mg} \mathrm{kg}^{-1} /$ day) and combined doses of MT and ALA for 60 days. Rats in group $\mathrm{C}$ were orally exposed to $22.9 / 5.71$, 45.6/11.4 and 91.4/22.9 $\mathrm{mg} \mathrm{kg}^{-1} /$ day of LPV/r for 60 days. Rats in groups D-F were exposed to $10 \mathrm{mg} \mathrm{kg}^{-1} / \mathrm{day}_{\text {ay }} \mathrm{MT}$, $10 \mathrm{mg} \mathrm{kg}^{-1} / \mathrm{day}$ of ALA and combined doses of MT and ALA prior to oral exposure to LPV/r (22.9/5.71, 45.6/11.4 and $91.4 / 22.9 \mathrm{mg} \mathrm{kg}^{-1} /$ day) for 60 days, respectively.

\section{Collection of sample for semen analysis}

Rats were sacrificed using diethyl ether at the end of 60 days of drug exposure and blood was collected through 
cardiac puncture in a sterile sample container and allowed to clot. The blood was centrifuged at 1200 for 15 min and serum extracted for testosterone evaluation. The caudal epididymis was removed and placed in a petri dish containing $3.0 \mathrm{~mL}$ of $\mathrm{NaHCO}_{3}$ buffered Tyrode's lactate solution. Several incisions about $91 \mathrm{~mm}$ were made on it and semen was drawn into a plastic transfer pipette and transferred into 5 $\mathrm{mL}$ test tubes and was then shaken for homogeneity and dispersal of sperm cells (Amelar et al., 1973).

\section{Evaluation of sperm parameters and serum testosterone}

Sperm count, motility, viability, abnormal sperm cells (morphology), debris, and primordial sperm cells were evaluated using standard laboratory technique (WHO, 1999) while serum testosterone was measured as reported by Tietz (1995).

\section{Statistical analysis}

The results were analyzed using Graph pad prism 5 statistical packages and ANOVA and differences between samples were determined by Dunnett's Multiple Comparison Test. Results are expressed as mean \pm standard error of mean (S.E.M). Statistical significance was set at $\mathrm{P}<0.05$.

\section{Results}

Sperm count, sperm motility, sperm viability and serum testosterone levels were increased, while sperm debris, abnormal sperm cells (morphology) and primordial sperm cells were decreased in rats treated with MT and ALA. However, effects were not significant $(\mathrm{P}>0.05)$ when compared to placebo control. On the other hand, significant reductions $(\mathrm{P}<0.05)$ in sperm debris, abnormal sperm cells (morphology) and primordial sperm cells were observed in rats that received combined treatment with MT and ALA when compared to placebo control (Table 1). Sperm count, sperm motility, sperm viability and serum testosterone levels were significantly $(\mathrm{P}<0.05)$ decreased in a dose-dependent manner in rats orally exposed to 22.9/5.71 - 91.4/22.9 $\mathrm{mg} \mathrm{kg}-1 /$ day of $\mathrm{LPV} / \mathrm{r}$ for 60 days when compared to pla- cebo control (Table 2 and 3). However, the above sperm parameters and serum testosterone levels were significantly $(\mathrm{P}<0.05)$ increased in rats administered with MT and ALA prior to the administration of 22.9/5.71 - 91.4/22.9 $\mathrm{mg} \mathrm{kg}^{-1} /$ day of LPV/r when compared to LPV/r treated rats. It is worthy of note that the highest and significant $(\mathrm{P}<0.05)$ levels of sperm count, sperm motility, sperm viability and serum testosterone levels were observed in rats administered concurrently with MT and ALA when compared to individual doses of MT and ALA (Table 2 and 3). Furthermore, abnormal sperm cells (morphology), debris and primordial sperm cells were significantly $(\mathrm{P}<0.05)$ and in a dose-dependent manner increased in rats administered with 22.9/5.71 - 91.4/22.9 $\mathrm{mg} \mathrm{kg}^{-1} /$ day of LPV/r for 60 days when compared to placebo control. However, the above sperm parameters were decreased in rats administered with individual doses of MT and ALA prior to the administration of 22.9/5.71 - 91.4/22.9 $\mathrm{mg} \mathrm{kg}^{-1} / \mathrm{day}$ of LPV/r. The observed decreases differ significantly $(\mathrm{P}<0.05)$ when compared to LPV/r-treated rats. Interestingly, decreases in abnormal sperm cells (morphology), debris and primordial sperm cell levels were lowest and significantly $(\mathrm{P}<0.05)$ different in rats administered with combined doses of ALA and MT when compared to individual doses of MT and ALA (Table 2 and 3).

\section{Discussion}

This study evaluated the effects of MT and ALA on sperm parameters and serum testosterone levels of LPV/rtreated albino rats. In the present study, sperm count, motility, viability and serum testosterone were increased, while abnormal sperm cells (morphology), debris and primordial sperm cells were decreased in rats administered with MT and ALA. The effects on these parameters were highest in rats co-treated with MT and ALA. These observations are consistent with previous reports (Bustos-Obregón, et al., 2013; Nasiraei-Moghadam et al., 2014). On the contrary, sperm counts, sperm viability, sperm motility and serum testosterone levels were decreased whereas abnormal sperm cell (morphology), debris and primordial sperm cells were increased in a dose-dependent manner in LPV/r - treated rats. These results are also in conjunction with ear-

Table 1. Effects of melatonin and alpha lipoic acid on sperm parameters and serum testosterone levels of male albino rats

\begin{tabular}{lccccccc}
\hline \hline Drug & $\begin{array}{c}\text { Sperm count } \\
\left(10^{6} \mathrm{~mL}^{-1}\right)\end{array}$ & $\begin{array}{c}\text { Abnormal } \\
\text { sperm cells (\%) }\end{array}$ & Motility (\%) & Debris (\%) & $\begin{array}{c}\text { Primordial } \\
\text { sperm cells \%) }\end{array}$ & $\begin{array}{c}\text { Sperm viability }(\%) \\
\text { Serum testosterone } \\
(\mathrm{g} \mathrm{dL})\end{array}$ \\
Control & $66.7 \pm 8.03$ & $12.0 \pm 0.41$ & $64.7 \pm 8.85$ & $12.3 \pm 0.41$ & $15.7 \pm 1.43$ & $69.7 \pm 7.06$ & $1.65 \pm 0.22$ \\
MT & $70.2 \pm 7.73$ & $10.0 \pm 0.81$ & $69.0 \pm 8.58$ & $10.8 \pm 0.32$ & $13.7 \pm 1.10$ & $75.7 \pm 6.00$ & $1.80 \pm 0.03$ \\
ALA & $69.2 \pm 5.10$ & $10.1 \pm 1.50$ & $67.7 \pm 6.65$ & $11.0 \pm 1.57$ & $14.0 \pm 1.21$ & $73.7 \pm 8.16$ & $1.70 \pm 0.01$ \\
MT + ALA & $72.5 \pm 6.64$ & $8.00 \pm 0.57 *$ & $71.3 \pm 5.31$ & $7.00 \pm 0.50 *$ & $8.30 \pm 1.30^{*}$ & $80.7 \pm 5.11$ & $2.10 \pm 0.06^{*}$ \\
\hline
\end{tabular}

$\mathrm{MT}=$ Melatonin; ALA $=$ Alpha lipoic acid. Data are expressed as mean \pm S.E.M. $(\mathrm{n}=5)$.

*Significant difference $(\mathrm{P}<0.05)$ when compared to control. 
Table 2. Effects of melatonin and alpha lipoic acid on sperm count, sperm motility, sperm viability and morphology of lopinavir/ritonavir treated male albino rats

\begin{tabular}{|c|c|c|c|c|c|}
\hline Dose $\left(\mathrm{mg} \mathrm{kg}^{-1}\right)$ & Control & $\overline{\mathrm{LPV} / \mathrm{r}}$ & MT+LPV/r & ALA+LPV/r & $\mathrm{MT}+\mathrm{ALA}+\mathrm{LPV} / \mathrm{r}$ \\
\hline \multicolumn{6}{|c|}{ Sperm count $\left(10^{6} \mathrm{~mL}^{-1}\right)$} \\
\hline $22.9 / 5.71$ & $66.8 \pm 8.03^{\mathrm{a}}$ & $31.8 \pm 4.18^{\mathrm{b}}$ & $60.3 \pm 7.48^{c}$ & $58.5 \pm 6.29^{c}$ & $68.5 \pm 6.65^{d}$ \\
\hline $45.9 / 11.4$ & $66.8 \pm 8.03^{\mathrm{a}}$ & $28.3 \pm 3.11^{\mathrm{b}}$ & $42.5 \pm 5.65^{\mathrm{c}}$ & $37.5 \pm 4.05^{\mathrm{c}}$ & $66.3 \pm 7.38^{\mathrm{d}}$ \\
\hline $91.4 / 22.9$ & $66.8 \pm 8.03^{\mathrm{a}}$ & $23.5 \pm 3.05^{b}$ & $37.3 \pm 6.48^{c}$ & $35.2 \pm 3.63^{c}$ & $64.5 \pm 5.96^{\mathrm{d}}$ \\
\hline \multicolumn{6}{|c|}{ Sperm motility (\%) } \\
\hline $22.9 / 5.71$ & $64.3 \pm 5.85^{\mathrm{a}}$ & $34.5 \pm 2.19^{\mathrm{b}}$ & $65.3 \pm 4.56^{\mathrm{c}}$ & $62.3 \pm 5.11^{\mathrm{c}}$ & $66.3 \pm 8.75^{\mathrm{d}}$ \\
\hline $45.9 / 11.4$ & $64.3 \pm 5.85^{\mathrm{a}}$ & $25.8 \pm 2.85^{\mathrm{b}}$ & $51.2 \pm 6.65^{\mathrm{c}}$ & $50.6 \pm 3.32^{\mathrm{c}}$ & $65.3 \pm 7.41^{\mathrm{c}}$ \\
\hline $91.4 / 22.9$ & $66.3 \pm 5.85^{\mathrm{a}}$ & $20.1 \pm 1.82^{\mathrm{b}}$ & $37.5 \pm 3.30^{c}$ & $35.2 \pm 2.48^{\mathrm{c}}$ & $63.7 \pm 5.32^{\mathrm{d}}$ \\
\hline \multicolumn{6}{|c|}{ Sperm viability (\%) } \\
\hline $22.9 / 5.71$ & $69.7 \pm 7.06^{\mathrm{a}}$ & $40.3 \pm 6.13^{\mathrm{b}}$ & $60.3 \pm 5.51^{\mathrm{c}}$ & $57.5 \pm 5.29^{c}$ & $74.3 \pm 6.30^{\mathrm{d}}$ \\
\hline $45.9 / 11.4$ & $69.7 \pm 7.06^{\mathrm{a}}$ & $25.7 \pm 2.10^{\mathrm{b}}$ & $45.4 \pm 6.05^{\mathrm{c}}$ & $40.5 \pm 4.05^{\mathrm{c}}$ & $68.2 \pm 7.20^{c}$ \\
\hline $91.4 / 22.9$ & $69.7 \pm 7.06^{\mathrm{a}}$ & $20.4 \pm 1.02^{\mathrm{b}}$ & $36.7 \pm 4.32^{\mathrm{c}}$ & $33.1 \pm 4.63^{\mathrm{c}}$ & $67.3 \pm 6.11^{\mathrm{d}}$ \\
\hline \multicolumn{6}{|c|}{ Sperm morphology (abnormal) (\%) } \\
\hline $22.9 / 5.71$ & $12.7 \pm 0.41^{\mathrm{a}}$ & $24.5 \pm 1.03^{b}$ & $11.0 \pm 0.11^{\mathrm{c}}$ & $10.5 \pm 1.23^{\mathrm{c}}$ & $9.00 \pm 0.17^{\mathrm{d}}$ \\
\hline $45.9 / 11.4$ & $12.7 \pm 0.41^{\mathrm{a}}$ & $30.8 \pm 2.27^{b}$ & $13.3 \pm 1.68^{\mathrm{c}}$ & $13.3 \pm 1.71^{\mathrm{c}}$ & $9.32 \pm 0.48^{\mathrm{c}}$ \\
\hline $91.4 / 22.9$ & $12.7 \pm 0.41^{\mathrm{a}}$ & $40.5 \pm 3.65^{b}$ & $18.4 \pm 1.65^{\mathrm{c}}$ & $20.8 \pm 2.58^{\mathrm{c}}$ & $11.5 \pm 0.18^{\mathrm{c}}$ \\
\hline
\end{tabular}

$\mathrm{LPV} / \mathrm{r}=$ Lopinavir/ritonavir; MT = Melatonin; $\mathrm{ALA}=$ Alpha lipoic acid. Data are expressed as mean \pm S.E.M. $(\mathrm{n}=5)$.

Values with different superscripts on the same row differ significantly at $\mathrm{P}<0.05$.

Table 3. Effects of melatonin and alpha lipoic acid on primordial sperm cells, sperm debris and serum testosterone levels of lopinavir/ritonavir treated male albino rats

\begin{tabular}{cccccc}
\hline \hline Dose $\left(\mathrm{mg} \mathrm{kg}^{-1}\right)$ & Control & LPV/r & MT+LPV/r & ALA+LPV/r & MT+ALA+LPV/r \\
\hline \multicolumn{5}{c}{ Primordial sperm cell (\%) } \\
$22.9 / 5.71$ & $15.7 \pm 1.43^{\mathrm{a}}$ & $27.3 \pm 1.16^{\mathrm{b}}$ & $14.0 \pm 0.20^{\mathrm{c}}$ & $15.3 \pm 1.32^{\mathrm{c}}$ & $12.0 \pm 0.11^{\mathrm{d}}$ \\
$45.9 / 11.4$ & $15.7 \pm 1.43^{\mathrm{a}}$ & $35.6 \pm 2.13^{\mathrm{b}}$ & $17.4 \pm 1.31^{\mathrm{c}}$ & $18.5 \pm 1.17^{\mathrm{c}}$ & $12.3 \pm 0.31^{\mathrm{c}}$ \\
$91.4 / 22.9$ & $15.7 \pm 1.43^{\mathrm{a}}$ & $40.2 \pm 2.25^{\mathrm{b}}$ & $20.4 \pm 2.15^{\mathrm{c}}$ & $21.8 \pm 2.31^{\mathrm{c}}$ & $13.2 \pm 0.97^{\mathrm{d}}$ \\
\multicolumn{5}{c}{ Sperm debris $(\%)$} \\
$22.9 / 5.71$ & $12.5 \pm 1.41^{\mathrm{a}}$ & $25.0 \pm 2.31^{\mathrm{b}}$ & $12.7 \pm 0.20^{\mathrm{c}}$ & $12.3 \pm 0.32^{\mathrm{c}}$ & $10.0 \pm 0.19^{\mathrm{d}}$ \\
$45.9 / 11.4$ & $12.5 \pm 1.41^{\mathrm{a}}$ & $37.1 \pm 2.15^{\mathrm{b}}$ & $14.5 \pm 1.31^{\mathrm{c}}$ & $15.6 \pm 1.15^{\mathrm{c}}$ & $10.3 \pm 0.35^{\mathrm{c}}$ \\
$91.4 / 22.9$ & $12.5 \pm 1.41^{\mathrm{a}}$ & $47.2 \pm 3.10^{\mathrm{b}}$ & $17.4 \pm 1.10^{\mathrm{c}}$ & $20.7 \pm 2.00^{\mathrm{c}}$ & $12.5 \pm 0.17^{\mathrm{d}}$ \\
& \multicolumn{5}{c}{ Serum testosterone $\left(\mathrm{g} \mathrm{dL} \mathrm{L}^{-1}\right)$} \\
$22.9 / 5.71$ & $1.65 \pm 0.22^{\mathrm{a}}$ & $1.00 \pm 0.05^{\mathrm{b}}$ & $1.61 \pm 0.15^{\mathrm{c}}$ & $1.50 \pm 0.17^{\mathrm{c}}$ & $1.71 \pm 0.03^{\mathrm{c}}$ \\
$45.9 / 11.4$ & $1.65 \pm 0.22^{\mathrm{a}}$ & $0.67 \pm 0.05^{\mathrm{b}}$ & $1.17 \pm 0.09^{\mathrm{c}}$ & $1.20 \pm 0.03^{\mathrm{c}}$ & $1.60 \pm 0.07^{\mathrm{d}}$ \\
$91.4 / 22.9$ & $1.65 \pm 0.22^{\mathrm{a}}$ & $0.32 \pm 0.01^{\mathrm{b}}$ & $0.83 \pm 0.07^{\mathrm{c}}$ & $0.79 \pm 0.01^{\mathrm{c}}$ & $1.47 \pm 0.17^{\mathrm{d}}$ \\
\hline
\end{tabular}

$\mathrm{LPV} / \mathrm{r}=$ Lopinavir/ritonavir; $\mathrm{MT}=$ Melatonin; $\mathrm{ALA}=$ Alpha lipoic acid. Data are expressed as mean \pm S.E.M. $(\mathrm{n}=5)$.

Values with different superscripts on the same row differ significantly at $\mathrm{P}<0.05$.

lier findings (Adaramoye et al., 2013; van Leeuwen et al., 2008). The altered levels of sperm parameters and serum testosterone in LPV/r-treated rats are signs of testicular damage (Adaramoye et al., 2015). The observed decreases in sperm count, sperm viability and serum testosterone levels in LPV/r-treated rats could be attributed to damage to Leydig cells and seminiferous tubules responsible for testosterone and sperm production, respectively (Abd-Allah et al., 2000). The reasons for the observed decreases in sperm motility in LPV/r-treated rats may be due to decreases in axonemal protein phosphorylation and sperm immobilization, which could lead to reduction in membrane flu- 
idity (Armstrong et al., 1999; de Lamirande and Gagnon 1992). Mitochondria present in sperm cells are required for energy production, hence direct mitochondria damage by LPV/r can decrease energy required for sperm motility (de Lamirande and Gagnon 1995; Kelton et al., 2008). Semen morphology as measured according to strict criteria appears to be the most informative semen measurement for discriminating between fertile and infertile men (Cuzick et al., 2001). In the current study, observed increases in abnormal sperm cells (morphology), sperm debris and primordial sperm cells in LPV/r-treated rats could be attributed to LPV/r-induced testicular oxidative stress, because studies have correlated oxidative stress with the production of immature sperm cells and abnormal sperm morphology (Ollero et al., 2001).

However, the observed alterations in sperm parameters and serum testosterone levels were ameliorated in rats administered with MT and ALA prior to LPV/r administration. Ameliorative effects were highest in rats co-administered with MT and ALA prior to LPV/r administration. These observations showed that MT and ALA have inherent therapeutic potential that could be of benefits in LPV/r associated testicular damage. Similarly, some authors have reported the protective effect of MT in cyclophosphamideinduced testicular toxicity in rats (Chabra et al., 2013). Also, El-Beshbishy and co-workers reported the ameliorative effect of ALA on sperm parameters of bisphenol-Atreated albino rats (El Beshbishy et al., 2013). The ameliorative effects of MT and ALA observed in the current study could be due to their antioxidant and anti-inflammatory effects. Also, the reason for the highest ameliorative effects observed with concurrent MT and ALA administration may be due to the potentiation of the activity of each other. Similarly, some authors have reported synergistic activity with concurrent MT and ALA administration (Adikwu et al., 2016). MT and its metabolite, ALA and its reduced form can scavenge varieties of oxidative radicals, thereby preventing oxidative stress-induced damage. They can also up-regulate the anti-oxidant activities of endogenous antioxidants (Cagnoli et al., 1995; Trujillo and Radi, 2002). MT and ALA can inhibit the production of pro-inflammatory cytokines (IL-1 $\beta$ and TNF- $\alpha$ ) and increase the level of anti-inflammatory cytokines (IL-4), thereby preventing inflammatory cell-induced testicular damage (Çakir et al., 2015; Carrasco et al., 2013). ALA can stimulate the recycling of tocopherol and ascorbic acid and in combination with its scavenging ability, maintain levels of protein thiols and therefore modulates endogenous antioxidants in the hypothalamus and epididymal sperm (Holmquist et al., 2007; Scholich et al., 1989). Othman et al. (2016) reported the ability of ALA to sustain the levels of cholesterol, sex-hormone-binding globulin (SHBG), dehydroepiandrosterone sulfate (DHEAS), glucose-6-phosphate dehydrogenase (G6PD) and 3 $\beta$-hydroxysteroid dehydrogenase (3BHSD). This provides adequate antioxidant milieu that can maintain a fine tuning of signal transduction mecha- nisms necessary for normal function of hypothalamus-testicular axis leading to normal secretion of testosterone and sperm production (Sundaram et al., 2006). ALA administration was reported to protect DNA and membrane proteins in epididymal sperm which was accompanied by a marked rise in sperm motility and a distinct decrease in abnormal sperm production (Sundaram et al., 2006). Furthermore, MT can increase GnRH pulsatile secretion; reduce prolactin levels and increase LH, FSH, and testosterone secretion by acting on the hypothalamus-pituitary axis which may facilitate spermatogenesis (Lincoln et al., 1997). It can stimulate the complete regeneration of testicular germ cells (Aziz et al., 2013), protect semen lipid, protein and DNA content against oxidative damage and sustained higher intracellular ATP concentrations in semen facilitating increase sperm motility (Cabrer et al., 2001; Succu et al., 2011).

\section{Conclusion}

This study observed that MT and ALA ameliorate $\mathrm{LPV} / \mathrm{r}$-induced testicular toxicity in rats. Ameliorative effects were highest in rats pretreated concurrently with MT and ALA. Based on the findings in the current study, MT and ALA could be used for the treatment of LPV/r associated testicular toxicity.

\section{Acknowledgements}

The authors appreciate the technical assistance of Mr. Woy Yirupe Department of Pharmacology, Faculty of Basic Medical Sciences, University of Port Harcourt, Choba, Rivers State.

\section{Conflict of interest statement}

The authors declare no conflict of interest.

\section{Funding sources}

The authors declare no sources of funding.

\section{References}

Abd-Allah, A.R., Aly, H.A., Mustafa, A.M., Abdel-Aziz, A.A., Hamada, F.M., 2000. Adverse testicular effects of some quinolone members in rats. Pharmacol. Res. 41, 211-219.

Adaramoye, O., Adesanoye, O.A., Adewumi, O.M., Akanni, O., 2012. Studies on the toxicological effect of nevirapine, an antiretroviral drug, on the liver, kidney and testis of male Wistar rats. Hum. Exp. Toxicol. 31(7), 676-685.

Adaramoye, O.A., Akanni, O.O., Adewumi, O.M., Owumi, S.E., 2015. Lopinavir/ritonavir, an antiretroviral drug, lowers sperm quality and induces testicular oxidative damage in 
rats. Tokai J. Exp. Clin. Med. 40(2), 51-57.

Adikwu, E., Braimbaifa, N., Obianime, A.W., 2016. Melatonin and alpha lipoic acid: possible mitigants for lopinavir/ ritonavir-induced renal toxicity in male Albino rats. Physiol. Pharmacol. 19, 232-240.

Ali, W.S., 2013. Comparative study between marjoram and alpha lipoic acid on potassium bromide induced oxidative stress in rats. World J. Dairy Food Sci. 8(1), 94-99.

Amelar, R.D., Dublin, L., Schoenfeld, C., 1973. Semen analysis: An office Technique. Urol. 2, 606-611.

Armstrong, J.S., Rajasekaran, M., Chamulitrate, W., Gatti, P., Hellstrom, W.J., Sikka, S.C., 1999. Characterization of reactive oxygen species induced effects on human spermatozoa movement and energy metabolism. Free Radic. Biol. Med. 26, 869-880.

Aziz, A., Metwally, D.H., Halla, G.B., 2013. The effect of stem cell therapy versus melatonin on the changes induced by busulfan in the testes of adult rat: histological and immunohistochemical studies. Egypt. J. Histol. 36, 175-184.

Bilginoğlu, A., Aydın, D., Özsoy, S., Aygün, H., 2014. Protective effect of melatonin on adriamycin-induced cardiotoxicity in rats. Arch. Turk. Soc. Cardiol. 42(3), 265-273.

Bujan, L., Sergerie, M., Moinard, N., Martinet, S., Porte, L., Massip, P., 2007. Decreased semen volume and spermatozoa motility in HIV-1-infected patients under antiretroviral treatment. J. Androl. 28, 444-452.

Bustos-Obregón, E., Poblete, D., Catriao, R., Del Sol, M., Fernandes, F.H., 2013. Melatonin protective role in mouse cauda epipidymal spermatozoa damage induced by sodium arsenite. Int. J. Morphol. 31(4), 1251-1256.

Cabrer, J., Burkhardt, S., Tan, D.X., Manchester, L.C., Karbownik, M., Reiter, R.J., 2001. Autoxidation and toxicant-induced oxidation of lipid and DNA in monkey liver: reduction of molecular damage by melatonin. Pharmacol.Toxicol. 89, 225-230.

Cagnoli, C.M., Atabay, C., Kharlamova, E., Manev, H., 1995. Melatonin protects neurons from singlet oxygen-induced apoptosis. J. Pineal. Res. 18, 222-226.

Çakir, T., Polat, C., Baştürk, A., Gül, M., Aslaner, A., 2015. The effect of alpha lipoic acid on rat kidneys in methotrexate induced oxidative injury. Eur. Rev. Med. Pharm. Sci. 19, 2132-2139.

Carrasco, C., Marchena, A., María, S., Holguín, A., 2013. Antiinflammatory effects of melatonin in a rat model of caeruleininduced acute pancreatitis. Cell. Biochem. Funct. 31(7), 585590 .

Casao, A., Mendoza, N., Pérez-Pé, R., 2011. Melatonin prevents capacitation and apoptotic-like changes of ram spermatozoa and increases fertility rate. J. Pineal. Res. 48(1), 39-46.

Chabra, A., Shokrzadeh, M., Naghshvar, F., Salehi, F., Ahmadi. A., 2013. Melatonin ameliorates oxidative stress and reproductive toxicity induced by cyclophosphamide in male mice. Hum. Exp. Toxicol. 2013, 1-11.

Collazos, J., 2007. Sexual dysfunction in the highly active antiretroviral therapy era. AIDS Rev. 9(4), 237-245.

Colson, A.E., Keller, M.J., Sax, P.E., 2002. Male sexual dysfunction associated with antiretroviral therapy. J. Acquir. Immune Defic. Syndr. 30, 27-32.

Cuzick, D.S., Overstreet, J.W., Factor-Litva, P.K., Brazil, C.K., 2011. Sperm morphology, motility and concentration in fertile and infertile men N. Engl. J. Med. 345, 1388-1393.

de Lamirande, E., Gagnon, C., 1992. Reactive oxygen species and human spermatozoa. II Depletion of adenosine triphosphate plays an important role in the inhibition of sperm motility. J Androl. 13, 379-386.

de Lamirande, E., C. Gagnon., 1995. Impact of reactive oxygen species on spermatozoa: A balancing act between beneficial and detrimental effects. Hum. Reprod. 10, 15-21.

Diehl, S., Vernazza, P., Trein, A., Schnaitmann, E., Grimbacher, B., Setzer, B., 2003. Mitochondrial DNA and sperm quality in patients under antiretroviral therapy. AIDS 17, 450-451.

Directive 2010/63/EU of the European Parliament and of the Council of 22 September 2010 on the protection of animals used for scientific purposes. Offic. J. Eur. Union L276, 3379.

Dulioust, E., Du, A.L., Costagliola, D., Guibert, J., Kunstmann, J.M., Heard, I., 2002. Semen alterations in HIV-1-infected men. Hum. Reprod. 17, 2112-2118.

Ekmekcioglu, C., 2006. Melatonin receptors in humans: biological role and clinical relevance. Biomed. Pharmacother. 60, 97108.

El Beshbishy, H., Aly, H., El-Shafey, M., Hesham, A., 2013. Lipoic acid mitigates bisphenol A-induced testicular mitochondrial toxicity in rats. Toxicol. Indust. Health 29(10), 875-887.

Holmquist, L., Stuchbury, G., Berbaum, K., Muscat, S., Young, S., Hager, K., 2007. Lipoic acid as a novel treatment for Alzheimer's disease and related dementias. Pharmacol. Ther. $1131,154-164$.

Hull, M., Harris, W.M., Lima, V., 2009. Lopinavir/ritonavir pharmacokinetics in a substitution of high-dose soft-gelatin capsule to tablet formulation. J. Clin. Pharmacol, 49, 155-61.

Kelton, T., 2008. Oxidative stress and male infertility - a clinical perspective. Human Reprod. Update 14(3), 243-258.

Lebda, M., Gad, S., Gaafar, H., 2014. Effects of lipoic acid on acrylamide induced testicular damage. Mater. Sociomed. 26(3), 208-212.

Lincoln, G.A., Clarke, I.J., 1997. Refractoriness to a static melatonin signal develops in the pituitary gland for the control of prolactin secretion in the ram. Biol. Reprod. 57, 460-467.

Minaii, B., Moayeri, A., Shokri, S., Roudkenar, M.H., 2014. Melatonin improve the sperm quality in forced swimming test induced oxidative stress in nandrolone treated Wistar rats. Acta Med. Iran. 52(7), 498-504.

Mirhoseini, M., Saki, G., Hemadi, M., Khodadadi, A., Mohammadi, J., 2014. Melatonin and testicular damage in busulfan treated mice. Iran. Red. Crescent. Med. J. 16(2), e14463.

Mukherjee, R., Banerjee, S., Joshi, N., Singh, P.K., Baxi, D., Ramachandran, A.V., 2011. A combination of melatonin and alpha lipoic acid has greater cardioprotective effect than either of them singly against cadmium-induced oxidative damage. Cardiovasc. Toxicol. 11(1), 78-88.

Nasiraei-Moghadam, S.K., Parivar. A., Ahmadiani, M., Movahhedin, M., Reza, V., 2014. Protective effect of melatonin against inequality-induced damages on testicular tissue and sperm parameters. Int. J. Fert. Ster. 7(4), 313-322.

Navari-Izzo, F., Quartacci, M.F., Sgherri, C., 2002. Lipoic acid: a unique anti-oxidant in the detoxification of activated oxygen species. Plant. Physiol. Biochem. 40, 463-70.

Ollero, M., Gil-Guzman, E., Lopez, M.C., Sharma, R.K., Agarwal, A., Larson, K.L., Evenson, D.K., 2001. Characterization of subsets of human spermatozoa at different stages of maturation: Implications in the diagnosis and treatment of male infertility. Hum. Reprod. 16, 1912-1921.

Othman, A.I., Edrees, G.M.,' El-Missiry, M.A., Ali, D.A., Aboel- 
Nour, M., Dabdoub, B.R., 2016. Melatonin controlled apoptosis and protected the testes and sperm quality against bisphenol A-induced oxidative toxicity. Toxicol. Ind Health 32(9), 1537-1549.

Packer, L., Cadenas, E., 2011. Lipoic acid: energy metabolism and redox regulation of transcription and cell signaling, $\mathrm{J}$. Clin. Biochem. Nutr. 48(1), 26-32.

Pavili, L., Daudin, M., Moinard, N., Walschaerts, M., Cuzin, L., Massip, P., 2013. Decrease of mitochondrial DNA level in sperm from patients infected with human immunodeficiency virus-1 linked to nucleoside analogue reverse transcriptase inhibitors. Fertil. Steril. 94, 2151-2156.

Peruma, P., Vupru, K., Khate, K., 2013. Effect of addition of melatonin on the liquid storage $\left(5^{\circ} \mathrm{C}\right)$ of Mithun (Bos frontalis). Int. J. Zool. ID 642632, 1-10.

Prahalathan, C., Selvakumar, E., Varalakshmi, P., 2006. Lipoic acid modulates adriamycin-induced testicular toxicity. Reprod. Toxicol. 21, 54-59.

Reyskens, K.M.S.E., Fisher, T.L., Schisler, J.C., O'Connor, W.G., Rogers, A.B., 2013. Cardio-metabolic effects of HIV protease inhibitors (lopinavir/ritonavir), PLoS ONE 8(9), e73347.

Sarabia, L., Espinoza-Navarro, O., Maurer, I., Ponce, C., BustosObregón, E., 2011. Protective effect of melatonin on damage in the sperm parameters of mice exposed to diazinon. Int. J. Morphol. 29(4), 1241-1247.

Sarabia, L., Maurer, I., Bustos-Obregón, E., 2009. Melatonin prevents damage elicited by the organophosphorus pesticide diazinon on mouse sperm DNA. Ecotoxicol. Environ. Saf. 72 (2), 663-668.

Scholich, H., Murphy, M.E., Sies, H., 1989. Antioxidant activity of dihydrolipoate against microsomal lipid peroxidation and its dependence on alpha tocopherol. Biochem. Biophys. Acta 1001, 256-261.

Shagirtha, K., Muthumani, M., Prabu, S., 2011. Melatonin abrogates cadmium induced oxidative stress related neurotoxicity in rats. Eur. Rev. Med. Pharmacol. Sci. 15, 1039-1050.
Sola, S., Mir, M.Q., Cheema, F.A., Khan-Merchant, N., Menon, R.G., Parthasarathy, S., Khan, B.V., 2005. Irbesartan and lipoic acid improve endothelial function and reduce markers of inflammation in the metabolic syndrome results of the irbesartan and lipoic acid in endothelial dysfunction (island) study. Circulation 111, 343-348.

Succu, S., Berlinguer, F., Pasciu, V., Satta, V., Leoni, G.G., Naitana, S., 2011. Melatonin protects ram spermatozoa from cryopreservation injuries in a dose-dependent manner. J. Pineal. Res. 50(3), 310-318.

Sundaram, K., Panneerselvam, K.S., 2006. Oxidative stress and DNA single strand breaks in skeletal muscle of aged rats: role of carnitine and lipoic acid. Biogerontology 72, 111-118.

Tietz, N.W., 1995. Clinical Guide to Laboratory Tests, third ed. W.B. Saunders Company, Philadelphia.

Trujillo, M., Radi R., 2002. Peroxynitrite reaction with the reduced and the oxidized forms of lipoic acid: New insights into the reaction of peroxynitrite with thiols. Arch. Biochem. Biophys. 397, 91-98.

van Leeuwen, E., Wit, F.W., Repping, S., EeftinckSchattenkerk, J.K.M., Reiss, P., van der Veen, F., Prins, J.M., 2008. Effects of antiretroviral therapy on semen quality. AIDS 22, 637642.

Ventura, P., Panini, R., Verlato C., 2000. Peroxidation indices and total antioxidant capacity in plasma during hyper homocysteinemia induced by methionine oral loading. Metabolism 49(2), 225-228.

World Health Organization (WHO), 1999. WHO Laboratory Manual for the Examination of Human Semen and Spermcervical Mucus Interaction, fourth ed. Cambridge University Press, United Kingdom.

Yeni, P.G., Hammer, S.M., Carpenter, C.C., Cooper, D.A., 2002. Antiretroviral treatment for adult HIV infection in 2002: Updated recommendations of the International AIDS Society-USA Panel. JAMA 288, 222-235. 


\title{
Влијание на мелатонин и алфа липоична киселина врз намалување на лопинавир/ритонавир-предизвиканата токсичност на тестисите кај албино стаорци
}

\author{
Елиас Адикву*, Брамбаифа Нелсон, Волфе Атубоведиа Обианиме \\ Инстиийуй за фармакологија, Факулиетеи за базични меоицински науки,

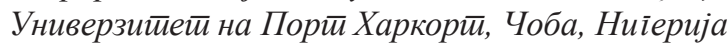

Клучни зборови: лопинавир/ритонавир, тестис, токсичност, антиоксиданси, стаорци.

Примената на лопинавир/ритонавир (LPV/r) е ограничена заради ризик од токсичен ефект на тестисите. Во ова истражување беше евалуиран ефектот на мелатонин (MT) и алфа липоична киселина (ALA) врз LPV/r-предизвиканата токсичност кај машки албино стаорци. За оваа цел, 85 стаорци беа поделени по случаен избор во 6 групи (A-F). Групите A1 (плацебо-контролирана) и А2 (третирана со растворувач), беа орално третирани со вода и етанолен раствор (1\%), соодветно. Стаорците од групата В беа третирани орално со МТ во доза од $10 \mathrm{mg} \mathrm{kg}^{-1} /$ ден, ALA (10 $\mathrm{mg} \mathrm{kg} \mathrm{g}^{-1} /$ ден) или нивна комбинација (MT и ALA). Стаорците од групата C беа орално третирани со следниве дози на LPV/r: 22.9/5.71 - 91.4/22.9 mg kg-1/ден. Стаорците од групите D-F беа третирани со $10 \mathrm{mg} \mathrm{kg}^{-1} /$ ден MT, $10 \mathrm{mg} \mathrm{kg}^{-1} /$ ден ALA или нивна комбинација пред да бидат орално изложени на LPV/r во дози од 22.9/5.71 - 91.4/22.9 mg kg-1/ден, соодветно. По 60-дневен третман, стаорците беа жртвувани; нивото на тестостерон беше определено во примероци од крв и серум. Тестисите беа изолирани заради анализа на семените карактеристики. Кај стаорците третирани со $\mathrm{LPV} / \mathrm{r}$ беше забележано статистички значајно и дозно-зависно намалување на бројот на сперматозоиди, нивната подвижност и виталност, како и серумското ниво на тестостерон, додека пак бројот на абнормални сперматозоиди, мртви и примитивни клетки беше зголемен во споредба со контролните стаорци. Меѓутоа, LPV/r-предизвиканите промени во однос на семените параметри и серумското ниво на тестостерон беа помалку изразени кај стаорците претходно третирани со MT и ALA. Најзначаен превентивен ефект покажа комбинираниот третман со MT и ALA. Оттука, може да се заклучи дека MT и ALA поседуваат потенцијал за намалување на токсичноста на тестисите предизвикана од LPV/r. 